American Journal of Applied Sciences 6 (11): 1868-1875, 2009

ISSN 1546-9239

(C) 2009 Science Publications

\title{
Camel's Milk Alleviates Oxidative Stress and Lipid Peroxidation Induced by Chronic Aluminum Chloride Exposure in Rat's Testes
}

\author{
Fahaid H. Al-Hashem \\ Department of Physiology, College of Medicine, King Khalid University, Abha 641, Saudi Arabia
}

\begin{abstract}
Problem statement: The present study was carried out to examine the effectiveness of Camel's milk in alleviating aluminum chloride $\left(\mathrm{AlCl}_{3}\right)$-induced oxidative stress and lipid peroxidation in rat testes. Approach: White albino male rats $(230-250 \mathrm{~g})$ were divided into three groups of 10 rats: A control group, treated with normal saline and two experimental groups, the $\mathrm{AlCl}_{3}$ treated group and the Camel's milk- $\mathrm{AlCl}_{3}$ treated group. The first experimental group, the $\mathrm{AlCl}_{3}$ treated group, received $0.5 \mathrm{mg} \mathrm{kg}{ }^{-1}$ of $\mathrm{AlCl}_{3}$ orally. The second experimental group was fed $1 \mathrm{~mL}$ of fresh Camel's milk 10 min prior to the administration of oral $\mathrm{AlCl}_{3}$. All rats were treated every day for 30 days. Lipid peroxidation, as determined by testicular concentration of Thiobarbituric Acid Reactive Substances (TBARS) and Hydroperoxide (HP) levels and the oxidative stress status, as measured by glutathione (GSH) levels, Superoxide Dismutase (SOD) and Catalase (CAT) activity, were evaluated in the rat testes. Results: Oral administration of $\mathrm{AlCl}_{3}$ induced lipid peroxidation and oxidative stress in rat testes, which was indicated by a significant increase in lipid peroxidation biomarkers (TBARS and HP) and a significant decrease in the GSH content and SOD and CAT activities. When rats received Camel's milk before being given $\mathrm{AlCl}_{3}$, lipid peroxidation and oxidative stress parameters were restored to normal levels. In the testes from rats fed Camel's milk TBARS and HP levels were significantly reduced and, conversely, GSH content, SOD and CAT activities were significantly increased compared to rats that received only $\mathrm{AlCl}_{3}$. Conclusion: Treatment with Camel's milk prior to $\mathrm{AlCl}_{3}$ alleviates $\mathrm{AlCl}_{3}$-associated hazards and protects testicular tissue from $\mathrm{AlCl}_{3}$ toxicity.
\end{abstract}

Key words: Camel's milk, rats, testes and oxidative stress

\section{INTRODUCTION}

The impact of aluminum on human health has been increasingly alarming in recent years. Aluminum, the most abundant metal, makes up about $8 \%$ of the Earth's crust and is found in combination with oxygen, silicon, fluorine and other elements in the soil, rocks, clay and gems $^{[1]}$. It has no known biological function ${ }^{[2]}$. Presently, aluminum utensils are widely used throughout the world, especially in developing countries $^{[3]}$. The use of such utensils may increase one's exposure to aluminum, particularly when used with salty, acidic or alkaline foods ${ }^{[4]}$. Aluminum and its salts are commonly used in daily life, as it was believed to be non-toxic and quickly excreted in the urine. However, this element, in fact, negatively impacts human health $^{[5]}$.

Aluminum is found mainly in food products and drinking water, where it is derived from both natural sources and from treatment methods ${ }^{[6]}$. The primary sources of aluminum that contribute to human exposure are corn, yellow cheese, salt, herbs, spices, tea, cosmetics, cookware, utensils and containers.
Additionally, it is widely included in food additives and toothpaste ${ }^{[7]}$. Aluminum compounds are also broadly used in medicines such as antacids, phosphate binders, buffered aspirin, vaccines and injectable allergens ${ }^{[8-10]}$. Environmental pollution from a variety of aluminumcontaining waste, especially from industrial waste water, increases human exposure beyond normal level ${ }^{[11]}$. Particulate matter discharged by cementproducing factories also contains a high amount of aluminum and those residing near such facilities are frequently exposed to elevated levels of this metal ${ }^{[12]}$. Aluminum is potentially toxic to humans. The Agency for Toxic Substances and Disease Registry (ATSDR) reported that aluminum accumulates mainly in the bone, liver, testes, kidneys and brain ${ }^{[13]}$. Patients on dialysis $^{[14]}$ or undergoing long-term treatment with total parental nutrition ${ }^{[15]}$ tend to accumulate this metal in different organs. The toxicological effects on humans include encephalopathy ${ }^{[14]}$, bone disease ${ }^{[16]}$, anemia ${ }^{[17]}$ and skeletal system disease ${ }^{[18]}$. It may also be a contributing factor for the development of Alzheimer's disease ${ }^{[19]}$ though the evidence remains contradictory ${ }^{[18-20]}$. 
Investigations in humans and experimental animal models provide evidence for the reproductive toxicity of aluminum exposure in males. However, information concerning the negative effects of aluminum on the male reproductive system is still very limited. It has been reported that there is a strong correlation between high aluminum contents in human testes, Leydig cells, spermatozoa, seminal plasma, blood and urine with impaired sperm quality and viability ${ }^{[21-23]}$. Suppressed testosterone production, sexual behavior and fertility were also observed in animals exposed to aluminum $^{[24-26]}$. Necrosis of spermatocytes and a significant decrease in fertility were demonstrated in male mice treated intraperitoneally with aluminumnitrate ${ }^{[27]}$. In addition, the presence of $\mathrm{AlCl}_{3}$ in drinking water has a suppressive effect on the fertility of male rats $^{[28]}$. A significant decrease in ejaculate volume, sperm concentration, total sperm output, sperm motility, total motile sperm per ejaculate, packed sperm volume, total functional sperm fraction, normal and live sperm and an increase in dead and abnormal sperm were all demonstrated in a study of Yousef et al. evaluating rabbits orally administered $\mathrm{AlCl}_{3}{ }^{[25]}$. Furthermore, $\mathrm{AlCl}_{3}$ exposure can lead to testicular injuries, especially as a result of increased oxidative stress $^{[25-28]}$. Exley ${ }^{[29]}$ and Yousef et al. ${ }^{[25]}$ have reported that aluminum exerts a pro-oxidant activity and promotes oxidation both in vitro and in vivo. Additionally, in rabbits, $\mathrm{AlCl}_{3}$ can induce free radical generation and inhibit antioxidant enzymes and other components of the antioxidant system in a variety of organs including the liver, testis, kidney, lung and brain $^{[30]}$.

Camel's milk is different from other ruminant milk; it is low in cholesterol, protein and sugar, but high in minerals (sodium, potassium, iron, copper, zinc and magnesium), vitamins (A, $\mathrm{B}_{2}, \mathrm{C}$ and $\left.\mathrm{E}\right)$ and insulin ${ }^{[31]}$. It has no allergic properties and can be consumed by lactase-deficient individuals and those with weak immune systems ${ }^{[31]}$. The milk is thought to have medicinal properties. In the Sahara, fresh butter from Camel's milk is often used as a base for cosmetics and pharmaceuticals ${ }^{[32]}$. A number of metabolic and autoimmune diseases are successfully being treated with Camel's milk. For example, in India, Camel's milk is therapeutically used to treat dropsy, jaundice, splenic problems, tuberculosis, asthma, anemia, piles and diabetes $^{[32]}$. A beneficial role for raw Camel's milk in the treatment of patients with chronic pulmonary tuberculosis has also been observed ${ }^{[33]}$.

To the best of our knowledge, no study has yet dealt with the therapeutic effect of Camel's milk in alleviating $\mathrm{AlCl}_{3}$ toxicity on rat testes. Therefore, one aim of the present study is to determine the effect of $\mathrm{AlCl}_{3}$ on oxidative stress status and on the activity of antioxidant enzymes in the testes. A second aim of the current report is to also investigate the potential protective effect of feeding oral Camel's milk prior to $\mathrm{AlCl}_{3}$ exposure in vivo.

\section{MATERIALS AND METHODS}

Milk samples: Daily Camel's milk samples were collected early in the morning from a camel farm in the Abha area (Southeastern region of Saudi Arabia). Milk was collected from camels by hand milking as is normally practiced by the farmers of the area. Samples were collected in sterile screw bottles and kept in cool boxes until they were transported to the laboratory. $\mathrm{AlCl}_{3}$ was purchased from Aldrich Chemical Company (MilwaukeeWis, USA).

Dose determination: In 1989, the FAO/WHO Expert Committee on Food Additives reported that the daily intake of aluminum in children ranged between 2 and 6 $\mathrm{mg}$ and in adults, it varied between 6 and $14 \mathrm{mg}^{[34-36]}$. Therefore, the daily intake of aluminum in an adult with a mean body weight $70 \mathrm{~kg}$ ranges between $0.1 \mathrm{mg}$ and $0.2 \mathrm{mg} \mathrm{kg}^{-1}$ body weight. According to the guidelines published by the Drugs Institute ${ }^{[37]}$, established from animal studies, a drug dosage to rodents should be 4-to 10 -fold higher than a human dose. In our study, rats received a daily oral dose of $0.5 \mathrm{mg}$ of $\mathrm{AlCl}_{3}\left[\mathrm{AlCl}_{3} \times 6\right.$ $\left.\mathrm{H}_{2} \mathrm{O}\right] \mathrm{kg}^{-1}$ of body weight, this doses were in a 6 -fold excess over the minimal dose and 2.8-fold over the maximal dose and, on average, 4-fold higher than the human dose.

Animals and Experimental procedure: White albino male rats $(230-250 \mathrm{~g})$ were supplied by the animal house at the medical faculty of King Khalid University. The rats were housed in standard plastic cages (10 rats/cage) in an environmentally controlled room (constant temperature $25-27^{\circ} \mathrm{C}$, with $12 \mathrm{~h}$ light/dark cycle) before and during the experiments. The rats were fed a "standard lab diet". Rats were given ad libitum access to food and water. The Physiology Department committee of King Khalid University approved the design of the experiments and the protocol follows their guidelines. Three groups of 10 rats were used for the experiments. All treatments were given using a gavage needle, everyday for 30 days. The groups were treated as follows: Group 1 received a daily dose of $1 \mathrm{~mL}$ normal saline (control group); Group 2 received $1 \mathrm{~mL}$ dose of a solution containing $0.5 \mathrm{mg} \mathrm{kg}^{-1}$ body weight of $\mathrm{AlCl}_{3}$ orally daily and 
named $\mathrm{AlCl}_{3}$-treated group; Group 3, Camel's milk$\mathrm{AlCl}_{3}$ treated group, was treated daily with an oral dose of $1 \mathrm{~mL}$ Camel's milk followed 10 min later by an oral administration of $1 \mathrm{~mL}$ of $\mathrm{AlCl}_{3}\left(0.5 \mathrm{mg} \mathrm{kg}^{-1}\right)$ solution.

Preparation of testes homogenate: At the end of day 30 , both testes of each rat were quickly removed, trimmed of attached tissues, washed in ice-cold, isotonic saline and blotted individually on ash-free filter paper, The tissues were then homogenized separately in $0.1 \mathrm{M}$ Tris-HCl buffer, $\mathrm{pH}$ 7.4, using a Potter-Elvejham homogenizer at $4{ }^{\circ} \mathrm{C}$ and a dilution factor of 4 . The crude tissue homogenate was then centrifuged at a speed of $9000 \mathrm{rpm}$ for $15 \mathrm{~min}$ in a cold centrifuge and the supernatant was kept at $-20^{\circ} \mathrm{C}$ for estimation of Thiobarbituric Acid Reactive Substances (TBARS), lipid hydroperoxides (HP), reduced Glutathione (GSH), Superoxide Dismutase (SOD) and Catalase Activity (CAT).

Biochemical analysis: The concentration of TBARS in the testes homogenate was determined by the method from Okhaw $^{[38]}$. In brief, the reaction mixture contained $0.1 \mathrm{~mL}$ of tissue homogenate, $0.2 \mathrm{~mL}$ of sodium dodecyl sulfate, $1.5 \mathrm{~mL}$ of acetic acid and $1.5 \mathrm{~mL}$ of aqueous solution of TBA. The $\mathrm{pH}$ of $20 \%$ acetic acid was pre-adjusted with $1 \mathrm{M} \mathrm{NaOH}$ to 3.5 . The mixture was made up to $4 \mathrm{~mL}$ with distilled water and heated at $95^{\circ} \mathrm{C}$ for $1 \mathrm{~h}$ in a water bath. After cooling, $1 \mathrm{~mL}$ of distilled water and $5 \mathrm{~mL}$ of a mixture of $n$-butanol and pyridine (15:1) were added and the mixture was shaken vigorously on a vortex mixer. The absorbance of the upper organic layer was read at $532 \mathrm{~nm}$. The values were expressed as $\mathrm{mM} / 100 \mathrm{~g}$ of tissues.

The estimation HP was done by the method described by Jiang ${ }^{[39]}$ in which $0.1 \mathrm{~mL}$ of tissue homogenate (supernatant) was treated with $0.9 \mathrm{~mL}$ of fox reagent $(88 \mathrm{mg}$ of butylated hydroxytoluene, $7.6 \mathrm{mg}$ of xylenol orange and $9.8 \mathrm{mg}$ of ammonium iron sulfate added to $90 \mathrm{~mL}$ of methanol and $10 \mathrm{~mL}$ of $250 \mathrm{mM}$ sulfuric acid) and incubated at $37^{\circ} \mathrm{C}$ for $30 \mathrm{~min}$. The color development was read at $560 \mathrm{~nm}$. Hydrogen peroxidase was expressed as $\mathrm{mM} / 100 \mathrm{~g}$ of tissues.

The GSH content of the homogenate was measured at $412 \mathrm{~nm}$ using the method described by Sedlak and Lindsay ${ }^{[40]}$ The homogenate was precipitated with $50 \%$ trichlora acetic acid and then centrifuged at $1000 \mathrm{rpm}$ for $5 \mathrm{~min}$. The reaction mixture contained $0.5 \mathrm{~mL}$ of supernatant, $2.0 \mathrm{~mL}$ of Tris-EDTA buffer $(0.2 \mathrm{M}$; pH $8.9)$ and $0.1 \mathrm{~mL}$ of $0.01 \mathrm{M}$ 5.5'-dithio-bis-2nitrobenzoic acid. The solution was kept at room temperature for $5 \mathrm{~min}$ and then read at $412 \mathrm{~nm}$ on the spectrophotometer. The values are expressed as $\mathrm{mM} / 100 \mathrm{~g}$ of tissues.

CAT and SOD activity was assayed using commercially available kits and performed according to manufacture's instruction (Biovision, K773-100 and K335-100, respectively).

Statistical analysis: At different stages of the study, the collected data were compiled and fed into an IBM computer. The SPSS package version 10 was used for standard statistical analysis. Data are given as the mean \pm SD. Student's t-test was used to determine the difference observed among various groups and $p<0.05$ was considered statistically significant.

\section{RESULTS}

Table 1 shows the testicular concentration of TBARS, HP and GSH in the control and the two experimental groups. The levels of TBARS and HP in the $\mathrm{AlCl}_{3}$ group were significantly higher when compared to the control group. Also, there was a significant decrease in the concentration of GSH in the testes of rats from the $\mathrm{AlCl}_{3}$ group. However, oral administration of Camel's milk before administration of $\mathrm{AlCl}_{3}$ restored the above mentioned parameters to their normal levels. It significantly reduced TBARS $(75.94 \pm 0.90 \%)$ and HP levels $(31.51 \pm 0.96 \%)$ and significantly increased GSH content $(152 \pm 6.62 \%)$.

Activities of SOD and CAT in the rat's testes are shown in Table 2. The activity of these two enzymes was significantly decreased in the $\mathrm{AlCl}_{3}$ group.

Table 1: Levels of Thiobarbituric Acid-Reactive Substances (TBARS), Hydrogen Peroxide (HP) and reduced Glutathione (GSH) in the testes of treated rats

\begin{tabular}{llll}
$\begin{array}{l}\text { Parameters } \\
\left(\mathrm{mM} \mathrm{g}^{-1} \text { of }\right. \\
\text { tissue })\end{array}$ & $\begin{array}{l}\text { Control } \\
\text { group }\end{array}$ & $\begin{array}{l}\mathrm{ALCl}_{3} \\
\text { group }\end{array}$ & $\begin{array}{l}\text { Camel's } \\
\text { milk-ALCl } \\
\text { group }\end{array}$ \\
\hline TBARS & $0.88 \pm 0.037$ & $3.24 \pm 0.212^{*}$ & $0.78 \pm 0.028^{*}$ \\
$\mathrm{HP}$ & $75.22 \pm 2.76$ & $108.96 \pm 2.36^{*}$ & $74.64 \pm 2.31^{*}$ \\
$\mathrm{GSH}$ & $59.82 \pm 1.58$ & $22.70 \pm 1.96^{*}$ & $57.18 \pm 3.92^{*}$ \\
\hline *: Values are statistically & significant at p<0.05 & $\mathrm{ALCl}_{3}$ group \\
compared with control group; Camel's milk $\mathrm{ALCl}_{3}$ group rats \\
compared with $\mathrm{ALCl}_{3}$-treated group)
\end{tabular}

Table 2: Superoxide Dismutase (SOD) and Catalase (CAT) activity in testes of treated rats

\begin{tabular}{|c|c|c|c|}
\hline $\begin{array}{l}\text { Parameters } \\
\text { (U mg } \\
\text { of protein) }\end{array}$ & $\begin{array}{l}\text { Control } \\
\text { group }\end{array}$ & $\begin{array}{l}\mathrm{ALCl}_{3} \\
\text { group }\end{array}$ & $\begin{array}{l}\text { Camel's } \\
\text { milk-ALCl }{ }_{3} \\
\text { group }\end{array}$ \\
\hline SOD & $13.16 \pm 0.74$ & $8.16 \pm 0.59 *$ & $12.94 \pm 0.51^{*}$ \\
\hline CAT & $91.55 \pm 2.47$ & $41.48 \pm 1.87^{*}$ & $86.68 \pm 1.76^{*}$ \\
\hline
\end{tabular}

*: Values are statistically significant at $\mathrm{p}<0.05 \quad\left(\mathrm{ALCl}_{3}\right.$ group compared with control group; Camel's milk $\mathrm{ALCl}_{3}$ group rats compared with $\mathrm{ALCl}_{3}$-treated group) 
However, feeding rats Camel's milk alleviated the effects of $\mathrm{AlCl}_{3}$ and resulted in a significant increase in the amount of SOD and CAT, which was more profound on CAT activity. The activity of SOD increased to $58.91 \pm 6.09 \%$ and the CAT activity was increased to $109.1 \pm 5.88 \%$.

\section{DISCUSSION}

Chronic exposure to $\mathrm{AlCl}_{3}$ results a mineral imbalance. In biological systems, aluminum ions replace iron, increasing the amount of the free iron ${ }^{[41]}$. Free iron ions can catalyze hydrogen peroxide, generating hydroxyl radicals through Fenton's reaction $^{[42]}$ These radicals are able to initiate lipid peroxidation and cellular damage ${ }^{[25-27]}$. Also, aluminum has been reported to promote non-iron-induced lipid peroxidation $^{[42]}$, such as a oxidation of $\mathrm{NADH}^{[43]}$, which also leads to the formation of hydroxyl radicals ${ }^{[44]}$ There is great concern that exposure to aluminum causes reproductive toxicity in humans and animals ${ }^{[21-27]}$. Testicular tissues are vulnerable to oxidative injury ${ }^{[45]}$ and defective sperm function is associated with an increase in lipid peroxidationderived free radicals and impaired antioxidant defense ${ }^{[46]}$. TBARS and HP levels are regarded as good indicators of the degree of lipid peroxidation ${ }^{[47,48]}$.

In the present experiment, there was a significant increase in lipid peroxidation following $\mathrm{AlCl}_{3}$ exposure, determined by TBARS and HP levels in rat testes. Our result are in agreement with many authors who have reported a significant increase in TBARS and HP in the kidney, liver and brain of rats exposed to aluminum salts $^{[41,49-51]}$. Also, our findings correlate with those published by Yousef et al. ${ }^{[25]}$ who demonstrated that, in rabbits orally treated with $\mathrm{AlCl}_{3}$, there was a significant increase in the level of TBARS in the seminal plasma.

Increased lipid peroxidation is, at least in part, due to an inhibition or alteration in the activity of nonenzymatic and enzymatic components of the oxidative system. This includes several components, such as glutathione peroxidase, GSH and NADPH ${ }^{[52]}$. GSH, an essential component of this system, serves as a cofactor for glutathione transferase, which helps to remove certain drugs and chemicals, as well as reactive molecules, from cells ${ }^{[52]}$. Moreover, GSH can directly detoxify hydroxyl radicals and is critical for mediating other key activities in the cell. Therefore, GSH is probably the most important antioxidant present in cells ${ }^{[52]}$.

The enzymatic antioxidant defense system, which includes SODs and CATs, helps protect cells from oxidative injuries $^{[52]}$. SOD catalyzes the rapid removal of superoxide radicals ${ }^{[37]}$ generating $\mathrm{H}_{2} \mathrm{O}_{2}$, which is eliminated by catalases ${ }^{[52]}$. These enzymes are present in the peroxisomes of nearly all aerobic cells. CAT protects the cell from the toxic effects of hydrogen peroxide by catalyzing its decomposition into molecular oxygen and water without the production of free radicals ${ }^{[50]}$.

In the present study, $\mathrm{AlCl}_{3}$ exposure induced a significant decrease in GSH content and in SOD and CAT activities. The reduced GSH levels are in agreement with Orihuela et al. ${ }^{[53]}$, who reported that, at high doses, aluminum was able to induce oxidative stress in the intestinal mucosa. Oxidate stress was indicated by a significant increase in the concentration of the oxidized glutathione/reduced glutathione (GSSG/GSH) ratio. Additionally, aluminum might affect GSH synthesis by decreasing the activity of glutathione-synthase, a non-limiting step of the reaction, which would result in reduced GSH content ${ }^{[54]}$.

Decreased SOD activity is in agreement with several studies in which the authors reported that aluminum inhibited SOD activity in experimental animals ${ }^{[37,55,56]}$. Similarly, the inhibition of CAT activity was also reported in a study by Zatta et al. ${ }^{[57]}$ examining CAT activity in erythrocytes isolated from patients undergoing dialysis due to chronic renal failure. Furthermore, these results are in accordance with Nehru and Anand, who observed a significant decrease in SOD and CAT activity in the brain after aluminum exposure ${ }^{[50]}$. The decrease in enzymatic activity could be due to reduced synthesis of these enzymes in response to higher intracellular concentrations of aluminum $^{[50]}$.

We have reported previously in a similar study that Camel's milk can alleviate alterations in biochemical parameters and oxidative stress produced in the liver, kidney and RBC's of rats treated with aluminum chloride ${ }^{[58,59]}$. In this study, we reported similar findings in the testes of these rats. Feeding Camel's milk to rats prior to administration of $\mathrm{AlCl}_{3}$ resulted in normal TBARS, HP, GHS, SOD and CAT levels compared to rats treated with $\mathrm{AlCl}_{3}$ alone. It could be concluded that the protective effect of Camel's milk against aluminuminduced oxidative stress in the rat testes is due to its antioxidant properties and possible chelating effects on aluminum. Camel's milk was found to contain high concentrations of vitamins $\mathrm{A}, \mathrm{B}_{2}, \mathrm{C}$ and $\mathrm{E}$ and is very rich in magnesium and other trace elements ${ }^{[31]}$. These vitamins act as antioxidants and have been found to be useful in preventing toxicant-induced tissue injury ${ }^{[31]}$. Magnesium protects cells from heavy metals such as aluminum, mercury, lead, cadmium, beryllium and 
nickel, which explains why re-mineralization is so essential for heavy metal detoxification and chelating ${ }^{[60]}$. Additionally, magnesium deficiency has been associated with production of reactive oxygen species ${ }^{[60]}$. Magnesium protects the cell against damage from oxyradicals and assists in the absorption and metabolism of vitamins $\mathrm{B}, \mathrm{C}$ and $\mathrm{E}$, which play a big role in cell protection from free-radicals by functioning as antioxidants ${ }^{[61]}$. Furthermore, recent evidence suggests that vitamin E enhances GSH levels and may play a protective role in magnesium deficiency-induced cardiac lesions $^{[62]}$. Also, magnesium is essential for GSH biosynthesis because glutathione synthetase requires magnesium ions, along with $\gamma$-glutamyl cysteine, glycine and ATP, to form $\mathrm{GSH}^{[63]}$. Additionally, Camel's milk is rich in Zinc (Zn), which is a trace element essential for living organisms and for the activity of more than 300 enzymes $^{[31]}$. It also plays an important role in DNA replication, transcription and protein synthesis, influencing cell division and differentiation ${ }^{[63]}$. Notably, $\mathrm{Zn}$ is associated with many enzymes in the body and can prevent cellular damage through activation of the antioxidant system ${ }^{[64-66]}$. In fact, $\mathrm{Zn}$ is an essential component of the oxidant defense system $^{[66]}$. One study has shown that $\mathrm{Zn}$ deficiency in the diet paves the way for cell damage in the rat's testis ${ }^{[66]}$. Furthermore, $\mathrm{Zn}$ deficiency increases lipid peroxidation in various rat tissues and $\mathrm{Zn}$ supplementation corrects this impairment ${ }^{[66-69]}$. Interestingly, $\mathrm{Zn}$ has been reported to protect against cadmium-induced cellular toxicity in vitro ${ }^{[70]}$. This protection is probably due to Zn-mediated activity, limiting oxidative stress and apoptosis ${ }^{[71]}$.

\section{CONCLUSION}

In conclusion, the current study indicates that daily, oral administration of $\mathrm{AlCl}_{3}$ to rats for 30 days significantly led to increased oxidative stress and lipid peroxidation in the testes. In contrast, oral treatment with Camel's milk prior to $\mathrm{AlCl}_{3}$ administration maintained prevented $\mathrm{AlCl}_{3}$-induced elevations in oxidative stress and lipid peroxidation, suggesting a protective role for Camel's milk in aluminum-induced toxicity in rat testes.

\section{ACKNOWLEDGEMENT}

The researchers wish to thank Mr. Mahmoud Alkhateeb and Mr. Mohd Abbas (King Khalid University, College of Medicine) for their help in designing experiments and in performing the biochemical analysis.

\section{REFERENCES}

1. Sigel, H. and A.E. Sigel, 1988. Metal ions in dialysis demenia syndrome and aluminum intoxication. Nephron, 31: 1-10.

2. Farina, M., L.N. Rotta, F.A. Soares, F. Jardim and R. Jacques et al., 2002. Effects of aluminum sulfate on erythropoiesis in rats. Toxicology, 209: 29-37. http://www.ncbi.nlm.nih.gov/pubmed/12044547

3. Lin, J.L., Y.J. Yang, S.S. Yang and M.L. Leu, 1997. Aluminum utensile contribute to aluminum accumulation in patients with renal disease. Am. J. Kidney Dis., 30: 653-658. http://cat.inist.fr/?aModele=afficheN\&cpsidt=2081759

4. Sharma, P. and K. Mishra, 2006. Amelioration of fumonisin B1 hepatotoxicity in mice by depletion of $\mathrm{T}$ cells with anti-Thy-1.2. Reprod. Toxicol., 21: 313-321.

http://www.ncbi.nlm.nih.gov/pubmed/16690192

5. Osinska, E., D. Kanoniuk and A. Kusiak, 2004. Aluminum hemotoxicity mechanisms. Ann. Univ. Mariae Curie Sklodowska, 59: 411-416. http://www.ncbi.nlm.nih.gov/pubmed/16146022

6. Yokel, R.A. and P.J. McNamara, 2001. Aluminum toxicokinetics: An updated mini review. Pharmacol. Toxicol., 88: 159-167. http://www.ncbi.nlm.nih.gov/pubmed/11322172

7. Abbasali, K.M., T. Zhila and N. Farshad, 2005. Developmental toxicity of aluminum from high doses of $\mathrm{AlCl} 3$ in mice. J. Applied Res., 5: 575-579. http://www.jarcet.com/articles/Vol5Iss4/02Karimp our.pdf

8. Cannata, J., J. Briggs, R. Junor snd S. Fell, 1983. Aluminum hydroxide intake real risk of aluminum toxicity. Br. Med. J., 286: 1937-1938. http://www.ncbi.nlm.nih.gov/pmc/articles/PMC1548249/

9. Kaehny, W.D., A.P. Hegg and A.C. Alfrey, 1977. Gastrointestinal absorption of aluminum from aluminum containing antacids. New Engl. J. Med., 296: 1389-1390.

http://www.ncbi.nlm.nih.gov/pubmed/859546

10. Lione, A., 1985. Aluminum toxicity and the aluminum containing medication. J. Pharmacol. Ther., 29: 255-285.

11. Kloppel, H., A. Fliedner and W. Kordel, 1997. Behavior and endotoxicology of aluminum in soil and water. Review of the scientific literature. Chemosphere, 35: 353-363.

12. Fatima, S.K., P.A. Prabhavathi, P. Padmavathi and P.P. Reddy, 2001. Analysis of chromosomal aberrations in men occupationally exposed to cement dust. Mutat. Res., 490: 179-186. http://www.ncbi.nlm.nih.gov/pubmed/11342243 
13. Agency for Toxic Substances and Disease Registry (ATSDR), 1990. Toxicological profile for aluminum. US Department of Health and Human Services. Public Health Service.

14. Alfrey, A.C., G.R. LeGendre and W.D. Kaehny, 1976. The dialysis encephalopathy syndrome. Possible aluminum intoxication. New Engl. J. Med., 294: 184-188. http://www.ncbi.nlm.nih.gov/pubmed/1244532

15. Klein, G.L., 1993. Aluminum and hepatobiliary complications of total parenteral nutrition. Gastroenterology, $\quad 10$ : 1583-1584. http://www.ncbi.nlm.nih.gov/pubmed/8343199

16. Ward, M.K., T.G. Feest, H.A. Ellis, I.S. Parkinson and D.N. Kerr, 1978. Osteomalacic dialysis osteodystrophy: Evidence for a water-borne aetiological agent, probably aluminum. Lancet, 22: 841-845.

http://www.ncbi.nlm.nih.gov/pubmed/76795

17. Short, A.I., R.J. Winney and J.S. Robson, 1980. Reversible microcytic hypochromic anaemia in dialysis patients due to aluminum intoxication. Proc. Eur. Dial. Transplant. Assoc., 17: 226-233. http://www.ncbi.nlm.nih.gov/pubmed/7243773

18. Gupta, V.B., G. Anitha, M.L. Hegda, L. Zecca and R.M. Garruto et al., 2005. Aluminum in Alzheimer's disease: Are we still at a crossroad? Cell Mol. Life Sci., 62: 143-158. http://www.ncbi.nlm.nih.gov/pubmed/15666086

19. Campbell, A., 2002. The potential role of aluminum in Alzheimer's disease. Nephrol. Dial. Transplant., $\quad 17$ : 17-20. http://cat.inist.fr/?aModele $=$ afficheN\&cpsidt $=1359$ 3102

20. Flaten, T., 2001. Aluminum as a risk factor in Alzheimer's disease, with emphasis on drinking water. Brain Res. Bull, 55: 187-196.

21. Reusche, E., B. Lindner and H. Arnholdt, 1994. Widespread aluminum deposition in extracerebral organ systems of patients with dialysis-associated encephalopathy. Virchows Arch., 424: 105-112. DOI: $10.1007 / \mathrm{BF} 00197400$

22. Hovatta, O., E.R. Venalainen, L. Kuusimaki, J. Heikkila, T. Hirvi and I. Reima, 1998. Aluminum, lead and cadmium concentrations in seminal plasma and spermatozoa and semen quality in Finnish men. Hum. Reprod., 13: 115-119. http://www.ncbi.nlm.nih.gov/pubmed/9512240

23. Dawson, E.B., D.R. Evans, W.A. Harris and L.C. Powell, 2000. Seminal plasma tracemetal levels in industrial workers. Biol. Trace Elem. Res., $\quad 74$ : 97-105. http://www.ncbi.nlm.nih.gov/pubmed/11051584
24. Guo, C.H., Y.F. Lu and G.S.W. Hsu, 2005. The influence of aluminum exposure on male reproduction and offspring in mice. Environ. Toxicol. Pharmacol., 20: 135-141. DOI: 10.1016/j.etap.2004.11.007

25. Yousef, M.I., A.M. El-Morsy and M.S. Hassan, 2005. Aluminum-induced deterioration in reproductive performance and seminal plasma biochemistry of male rabbits: Protective role of ascorbic acid. Toxicology, 215: 97-107. DOI: 10.1016/j.tox.2005.06.025

26. Yousef, M.I., K.I. Kamel, M.I. El-Guendi and F.M. El-Demerdash, 2007. An in vitro study on reproductive toxicity of aluminum chloride on rabbit sperm: the protective role of some antioxidants. Toxicology, 239: 213-223. DOI: 10.1016/j.tox.2007.07.011

27. El-demerdash, F.M., 2004. Antioxidant effect of vitamin $\mathrm{E}$ and selenium on lipid peroxidation, enzyme activities and biochemical parameters in rats exposed to aluminum. J. Trace Elem. Med. Biol., 18: 113-121. http://www.ncbi.nlm.nih.gov/pubmed/15487771

28. Llobet, J.M., M.T. Colomina, J.J. Sirvent, J.L. Domingo and J. Corbella, 1995. Reproductive toxicology of aluminum in male mice. Fundam. Applied Toxicol., 25: 45-51.

29. Bataineh, H., M.H. Al-Hamood and A.M. Elbetieha, 1998. Assessment of aggression, sexual behavior and fertility in adult male rat following long-term ingestion of four industrial metals salts. Hum. Exp. Toxicol., 17: 570-579.

30. Exley, C., 2004. The pro-oxidant activity of aluminum. Free Radic. Biol. Med., 36: 380-387. http://www.ncbi.nlm.nih.gov/pubmed/15036357

31. Yousef, M.I., 2004. Aluminum-induced changes in hematobiochemical parameters, lipid peroxidation and enzyme activities of male rabbits: Protective role of ascorbic acid. Toxicology, 199: 47-57. http://www.ncbi.nlm.nih.gov/pubmed/15125998

32. Knoess, K.H., 1979. Milk production of the dromedary. Proceeding of the IFS Symposium Camels, Sudan, pp: 201-214.

33. Rao, M.B., R.C. Gupta and N.N. Dastur, 1970. Camels' milk and milk products. Ind. J. Dairy Sci., 23: 71-78.

34. Mal, G., D.S. Sena, V.K. Jain and M.S. Sahani, 2001. Therapeutic utility of camel milk as nutritional supplement in chronic pulmonary tuberculosis. Livestock Int., 4-8.

35. Gramiccioni, L., G. Ingrao, M.R. Milana, P. Santaroni and G. Tomassi, 1996. Aluminum levels in Italian diets and in selected foods from aluminum utensils. Food Addit. Contam., 13: 767. 
36. Starska, K., 1993. Aluminum in food. Rocz.Państw. Zakł. Hig., 44: 55.

37. Sepe, A., S. Costantini, L. Ciaralli, M. Ciprotti and R. Giordan, 2001. Evaluation of aluminum concentration in samples of chocolate and beverages by electrothermal atomic absorption spectrometry. Food Addit. Contam., 18: 788-796. http://www.ncbi.nlm.nih.gov/pubmed/11552746

38. WIOSNA/LATO., 2007. Biuletyn Iformacyjny. http://www.idn.org.pl/hemofilia/biuletyn27.pdf

39. Okhawa, H., N. Ohigni and K. Yagi, 1979. Assay of lipid peroxides in animal tissues by thiobarbituric acid reaction. Anal. Biochem., 95: 351.

40. Jiang, Z.Y., J.V. Hunt and S.D. Wolff, 1992. Ferrous ion oxidation in the presence of xylenol orange for detection of lipid hydroperoxides in low density lipoprotein. Anal. Biochem., 202: 384-391.

41. Sedlak, J. and R.H. Lindsay, 1968. Estimation of total protein bound and non-protein sulfhydryl groups in tissue with Ellmans reagent. Anal. Biochem., 25: 293-98.

42. Ward R.J., Y. Zhang and R.R. Crichton, 2001. Aluminum toxicity and iron homeostasis. J. Inorg. Biochem., 87: 9-14. DOI: 10.1016/S01620134(01)00308-7

43. Erstraeten, S.V. and P.I. Oteiza, 2000. Effects of $\mathrm{Al}(3+)$ and related metals on membrane phase state and hydration: Correlation with lipid oxidation. Arch. Biochem. Biophys., 375: 340-346. http://www.ncbi.nlm.nih.gov/pubmed/10700390

44. Kong, S., S. Liochev and I. Fridovich, 1992. Aluminum(III) facilitates the oxidation of NADH by the superoxide anion. Free Radic. Biol. Med., 13: 9-81.

45. Mendez-Alvarez, E., R. Soto-Otero, A. HermidaAmeijeiras, A.M. Lopez-Real and J.L. LabandeiraGarcia. 2002 Effects of aluminum and zinc on the oxidative stress caused by 6-hydroxydopamine autoxidation: Relevance for the pathogenesis of Parkinson's disease. Biochim. Biophys. Acta, 1586: 155-168. http://www.ncbi.nlm.nih.gov/pubmed/11959457

46. Aitken, R.J., J.S. Clarkson and S. Fishel, 1989. Generation of reactive oxygen species, lipid peroxidation and human sperm function. Biol. Reprod., 40: 183-197.

47. Storey, B.T., 1997. Biochemistry of the induction and prevention of lipoperoxidative damage in human spermatozoa. Mol. Hum. Reprod., 3: 203-214.

48. Jagetia, G.C. and T.K. Reddy, 2005. Modulation of radiation-induced alteration in the antioxidant status of mice by Naringin. Life Sci., 77: 780-794. http://www.ncbi.nlm.nih.gov/pubmed/15936352
49. Muriel, P., N. Alba, V.M. Perez-Alvarez, M. Shibayama and V.K. Tsutsumi, 2001. Kupffer cells inhibition prevents hepatic lipid peroxidation and damage induced by carbon tetrachloride. Comp. Biochem. Physiol. Toxicol. Pharmacol., 130: 219-226. http://www.ncbi.nlm.nih.gov/pubmed/11574291

50. Katyal, R., B. Desigan, C.P. Sodhi and S. Ojha, 1997. Oral aluminum administration and oxidative injury. Biol. Trace Elem. Res., 57: 125-130.

51. Nehru, B. and P. Anand, 2005. Oxidative damage following chronic aluminum exposure in adult and pup rat brains. J. Trace Elem. Med. Biol., 19: 203-208. http://www.ncbi.nlm.nih.gov/pubmed/16325537

52. Fraga, C.G., P.I. Oteiza, M.S. Golub, M.E. Gershwin and C.L. Keen, 1990. Effects of aluminum treated on brain lipid peroxidation. Toxicol. Lett., 51: 213-219.

53. Wu, D. and I. Cederbaum, 2003. Alcohol, oxidative stress and free radical damage. Alcohol. Res. Health, 27: 277-284. http://www.ncbi.nlm.nih.gov/pubmed/15540798

54. Orihuela, D., V. Meichtry, N. Pregi and M. Pizarro, 2005. Short-term oral exposure to aluminum decreases glutathione intestinal levels and changes enzyme activities involved in its metabolism. J. Inorg. Biochem., 99: 1871-1878.DOI: 10.1016/j.jinorgbio.2005.06.029

55. Alder, A.J., C. Caruso and G.M. Berlyn, 1995. The effect of aluminum on the vanadium-mediated oxidation of NADH. Nephron, 69: 34-40.

56. Atienzar, F., D. Desor, D. Burnel, J.M. Keller, P. Lehr and P. Vasseur, 1998. Effect of aluminum on superoxide dismutase activity in the adult rat brain. Biol. Trace Elem. Res., 65: 19-30.

57. Zatta, P., T. Kiss, M. Suwalsky and G. Berthon, 2002. Aluminum(III) as a promoter of cellular oxidation. Coord. Chem. Rev., 228: 271-284. http://cat.inist.fr/?aModele $=$ afficheN\&cpsidt $=1377$ 0057

58. Al-Hashem, F., 2009. Camel's milk protects against aluminum chloride-induced toxicity in the liver and kidney of white albino rats. Am. J. Biochem. Biotechnol., 5: 98-101. http://www.scipub.org/fulltext/ajbb/ajbb5398-109.pdf

59. Al-Hashem, F., 2009. Camel's milk protects against aluminum chloride-induced normocytic normocromic anemia, lipid peroxidation and oxidative stress in erythrocytes of white albino rats. Am. J. Biochem. Biotechnol., 5: 127-136. http://www.akademik.unsri.ac.id/download/journal /files/scipub/ajbb53127-136-16082009.pdf 
60. Martin, H., L Richert and A. Berthelot, 2003. Magnesium deficiency induces apoptosis in primary cultures of rat hepatocytes. The American society for nutritional sciences. J. Nutr., 133: 2505-2511.

http://cat.inist.fr/?aModele $=$ afficheN\&cpsidt $=1503$ 7175

61. Barbagallo, M., 1999. Effects of vitamin E and glutathione on glucose metabolism: Role of magnesium. Hypertension, 34: 1002-1006. http://www.ncbi.nlm.nih.gov/pubmed/10523398

62. Virginia, M., M.B. Smith, M.J. Brauner and W. PhiliMajerus, 1971. Glutathione biosynthesis in human erythrocytes. J. Clin. Invest., 50: 507-513.

63. Frederickson, C.J., 1989. Neurobiology of zinc and zinc containing neurons. Int. Rev. Neurobiol., 31: 145-238.

64. Powell, S.R., 2000. The antioxidant properties of zinc. J. Nutr., 130: 1447-1454. http://www.ncbi.nlm.nih.gov/pubmed/10801958

65. Ozturk, A., A.K. Baltaci, R.E. Mogulkoc Oztekina and A. Sivrikaya et al., 2003. Effects of zinc deficiency and supplementation on malondialdehyde and glutathione levels in blood and tissue of rats performing swimming exercise. Biol. Trace Elem. Res., 94: 157-166. http://www.ncbi.nlm.nih.gov/pubmed/12958407

66. Ozdemir, G. and F. Inanc, 2005. Zinc may protect remote ocular injury caused by intestinal ischemia reperfusion in rats. Tohoku J. Exp. Med., 206: 247-251.

http://www.ncbi.nlm.nih.gov/pubmed/15942153
67. Sato, M., I. Bremner, 1993. Oxygen free radicals and metalothionein. Free Radic. Biol. Med., 14: 325-327. http://www.ncbi.nlm.nih.gov/pubmed/8458590

68. Cai, Y.Q., H. Teranishi, K. Aoshima, T. Katoh, Y. Arai and N. Kasuya, 2001. Development of the fluorometric ELISA method for determination of alpha (1)-microglobulinuria in cadmium-polluted area in Japan. Int. Arch. Occup. Environ. Health, 507: 514-518. http://www.ncbi.nlm.nih.gov/pubmed/11697455

69. Shaheen, A.A. and A.A. El-Fattah, 1995. Effect of dietary zinc on lipid peroxidation, glutathione, protein levels and superoxide dismutase activity in rat tissues. Int. J. Biochem. Cell Biol., 27: 89-95. http://www.ncbi.nlm.nih.gov/pubmed/7757885?do $\mathrm{pt}=\mathrm{Abstract}$

70. Bray, T.M. and W.J. Bettger, 1990. The physiological role of zinc as an antioxidant. Free Radic. Biol. Med., 8: 281-291. http://www.ncbi.nlm.nih.gov/pubmed/2187766

71. Goering, P.L. and C.D. Klaassen, 1984. Zincinduced tolerance to cadmium hepatotoxicity. Toxicol. Applied Pharmacol., 74: 299-307. 